\title{
Technical note: Vitamin D-fortified Cheddar type cheese produced from concentrated milk
}

\author{
Jonathan Boivin-Piché, ${ }^{*} \dagger$ Jean-Christophe Vuillemard, $\dagger^{1}$ and Daniel St-Gelais ${ }^{*} \dagger$ \\ *Food Research and Development Center, Agriculture and Agri-Food Canada, 3600 boul. Casavant Ouest, St-Hyacinthe QC, Canada, J2S 8E2 \\ †Institut sur la Nutrition et les Aliments Fonctionnels, Centre de recherche STELA, Université Laval, Quebec City, QC, Canada, G1V 0A6
}

\begin{abstract}
The technological challenge related to cheese fortification with vitamin $\mathrm{D}$ is the loss of a large proportion of vitamin $\mathrm{D}$ during the wheying-off step. The use of ultrafiltration (UF) to concentrate the milk before vitamin D enrichment and cheese manufacturing could be a way to reduce the volume of whey and consequently the vitamin $\mathrm{D}$ losses in cheese whey. Control $(1.0 \times)$ and concentrated milks $(1.4 \times$ and $1.8 \times)$ were fortified with vitamin $\mathrm{D}$ at a concentration of $450 \mathrm{IU}$ per gram of milk. The $1.8 \times$ cheese milk concentration reduced slightly the vitamin D loss during the draining step (19.8\%) compared with the control cheese $(25.5 \%)$ and vitamin D remained stable during Cheddar cheese processing and ripening.
\end{abstract}

Key words: vitamin D, retention, stability, Cheddar, ultrafiltration

\section{Technical Note}

Vitamin D plays an important metabolic role in the human body. It improves the intestinal absorption of calcium and phosphorus and reduces the risk of developing bone-related diseases, various autoimmune diseases, and cancers (Institute of Medicine, 2011). Because of the low variety of food products naturally containing vitamin D (Combs, 2012) and the limited cutaneous synthesis in the Nordic countries (Holick, 2011), drinking milk, which is fortified at a rate of 41 IU per $100 \mathrm{~g}$ (Calvo and Whiting, 2013; Sacco, 2013) is an important source of vitamin D for Canadians. However, approximately $25 \%$ of Canadians do not meet the recommended dietary allowance $(50 \mathrm{nmol} / \mathrm{L})$, and more than one-third do not meet the recommended dietary allowance in winter (Whiting et al., 2011). Furthermore, an increased number of studies have shown that

Received October 27, 2015.

Accepted February 17, 2016

${ }^{1}$ Corresponding author: Jean-Christophe.Vuillemard@fsaa.ulaval.ca vitamin D deficiency is a worldwide problem (Holick and Chen, 2008; Lips, 2010).

Vitamin D-enriched cheese could be an alternative source of vitamin D. Previous studies have shown that vitamin $\mathrm{D}$ was not affected by milk pasteurization (Krauss, 1933; Wagner et al., 2008a; Kaushik et al., 2014) and remained relatively stable during Cheddar cheese manufacture (Kazmi et al., 2007; Wagner et al., 2008a) and ripening (Banville et al., 2000; Wagner et al., 2008a). Vitamin D was also uniformly distributed in the cheese (Wagner et al., 2008a) and did not affect the flavor (Ganesan et al., 2011). In addition, vitamin $\mathrm{D}$ in the cheese matrix was as bioavailable as the vitamin D absorbed as a supplement form (Wagner et al., 2008b). However, during cheese manufacturing, a large proportion of the added vitamin $\mathrm{D}$ is lost during the wheying-off step (Banville et al., 2000; Kazmi et al., 2007; Wagner et al., 2008a), making the valorization of the contaminated whey difficult.

Ultrafiltration has been applied to cheese manufacturing in many ways over the past $30 \mathrm{yr}$. Concentrated milk retentate can be used to enrich cheese milk for the production of cheese (St-Gelais et al., 1998, 2001) and to increase the cheese yields (Guinee et al., 1996, 2006). By reducing the amount of whey before cheese making, the use of ultrafiltration could also be useful to reduce the volume of whey and consequently to decrease the vitamin D losses during the wheying-off step. To our knowledge, this work is the first to report the effect of the cheese milk concentration by ultrafiltration as a mean to increase the vitamin D retention in Cheddar type cheese.

Pasteurized skim milk obtained from Laiterie Chalifoux Inc. (Sorel, QC, Canada) was concentrated by using an ultrafiltration system equipped with membranes HF-3043-25-60-PM10 (Koch Membrane Systems Inc., Wilmington, MA) operated as described by St-Gelais et al. (1992b). The UF retentate (11.67\% total proteins) was stored at $4^{\circ} \mathrm{C}$ until use. Skim milk $(0.17 \%$ milk fat $)$ and cream $(39.31 \%$ milk fat) obtained from Laiterie Chalifoux Inc. (Sorel, QC, Canada) were mixed with UF retentate to obtain 3 lots of milk (150 kg each) with a protein concentration of respectively $3.35(1 \times)$, 
$4.71(1.4 \times)$, and $6.01 \%(1.8 \times)$. Each milk protein to fat ratio was 0.91 . Standardized cheese milks were kept at $4^{\circ} \mathrm{C}$ overnight.

Lactococcus lactis ssp. cremoris (CUC-222, Cargill Texturizing Solutions, Waukesha, WI) was stored at $-80^{\circ} \mathrm{C}$ in $20 \%$ (wt/vol) reconstituted skim milk containing $5 \%$ (wt/vol) sucrose and $0.35 \%$ (wt/vol) ascorbic acid. The active culture was obtained after a subculture [inoculation rate of $10 \%$ (wt/wt)] in a $12 \%$ (wt/vol) reconstituted skim milk previously sterilized $\left(110^{\circ} \mathrm{C}, 10\right.$ $\min )$. After $16 \mathrm{~h}$ of incubation at $21^{\circ} \mathrm{C}$, the culture was cooled and maintained at $4^{\circ} \mathrm{C}$ for a maximum of $2 \mathrm{~h}$ before use.

Standardized cheese milks were fortified with $0.220 \%$ (wt/wt) of a 205,000 IU/g of vitamin D solution (Kingsway Chocolate Co. Ltd., Mississauga, ON, Canada) to obtain a concentration of $450 \mathrm{IU}$ per gram of milk, then pasteurized at $74^{\circ} \mathrm{C}$ for $16 \mathrm{~s}$ and cooled at $32^{\circ} \mathrm{C}$. Two 270-L cheese vats (Kusel Equipment Co., Watertown, WI) were filled with $100 \mathrm{~kg}$ of control milk $(1 \times)$ and $1.8 \times$ concentrated milk. The third cheese vat was filled with $130 \mathrm{~kg}$ of $1.4 \times$ milk. A $45 \% \mathrm{CaCl}_{2}$ solution Calsol (Chr. Hansen's Laboratory Ltd., Mississauga, ON, Canada) was added at a rate of $0.025,0.005$, and $0 \%$ ( $\mathrm{vol} / \mathrm{vol}$ ), in the $1 \times, 1.4 \times$, and $1.8 \times$ milks, respectively. To obtain the same time processing for each cheese production, the rates of inoculation and rennet addition were adjusted depending on milk concentration. The starter inoculum rate was 1.70, 1.82, and $1.94 \%$ (vol/ vol) for $1 \times, 1.4 \times$, and $1.8 \times$ cheese milks, respectively. After $50 \mathrm{~min}$ at $32^{\circ} \mathrm{C}$, a double-strength rennet ChyMax Extra (Chr. Hansen's Laboratory Ltd.) was added at a rate of $0.010,0.009$, and $0.008 \%(\mathrm{vol} / \mathrm{vol})$ in $1 \times$, $1.4 \times$, and $1.8 \times$ cheese milks, respectively, and then left to stand for $30 \mathrm{~min}$. The curds were cut in cubes of 1 $\mathrm{cm}^{3}$. Ten minutes later, the temperature was gradually increased from 32 to $38^{\circ} \mathrm{C}$ over $30 \mathrm{~min}$ and was maintained at this temperature until the wheying-off step, which occurred at $\mathrm{pH}$ 6.0. The temperature was then adjusted to $35^{\circ} \mathrm{C}$ for the cheddaring step. At a $\mathrm{pH}$ value of 5.2, curds were weighed, milled, and salted at a rate of $2.2 \%$ (wt/wt). The salted curds were allowed to rest for $15 \mathrm{~min}$ after which they were hooped and pressed overnight $(16 \mathrm{~h})$ at $2.76 \mathrm{bar}$. The pressed cheeses were vacuum-packaged and stored in a ripening room at $8^{\circ} \mathrm{C}$ for the first $30 \mathrm{~d}$, and then transferred at $4^{\circ} \mathrm{C}$ for an additional $60 \mathrm{~d}$.

The extraction of vitamin $\mathrm{D}$ was performed in a darkroom by using a method adapted from Kazmi et al. (2007) and Wagner et al. (2008a). The extracts were filtered through a $0.45-\mu \mathrm{m}$ polyvinyl fluoride filter (Canadian Life Science Inc., Dorval, QC, Canada) and stored in vials (Agilent Technologies, Mississauga, ON, Canada) until analysis. Vitamins $\mathrm{D}_{2}$ and $\mathrm{D}_{3}$ were quantified with an HPLC Agilent 1200 series system (Agilent Technologies) equipped with an UV detector set at $266 \mathrm{~nm}$. The absorbance data were recorded and integrated using the ChemStations LC 3D Systems Software (Agilent Technologies). The calibration curve and the retention times of both vitamins were determined using different concentrations (10-1,000 $\mathrm{IU} / \mathrm{mL}$ ) of pure vitamin $\mathrm{D}_{2}$ and $\mathrm{D}_{3}$ (Supelco, SigmaAldrich, St. Louis, MO) dissolved in the mobile phase [methanol:acetonitril:water (49.5:49.5:1 volume)]. A guard and a C18 column (Advanced Chromatography Technologies, Aberdeen, Scotland) were used for the analyses, which were performed at $23^{\circ} \mathrm{C}$, with a flow rate of $1 \mathrm{~mL} / \mathrm{min}$ after injection of $100-\mu \mathrm{L}$ samples. Retention time for vitamin $\mathrm{D}_{2}$ and $\mathrm{D}_{3}$ were 10.8 and $11.8 \mathrm{~min}$, respectively. In this study, the sum of vitamin $\mathrm{D}_{2}$ and vitamin $\mathrm{D}_{3}$ is presented.

The $\mathrm{pH}$ and acidity values of milk and whey were determined with a $\mathrm{pH}$ meter equipped with an automatic titration module (DL 15 Titrator, Mettler Toledo, Mississauga, ON, Canada) and a combined sealed glass electrode (ASI, Analytical Sensors \& Instruments Ltd., Sugar Land, TX). The $\mathrm{pH}$ values of cheeses were obtained with a TritraLab80 pH-meter (Radiometer, Rose-Scientific, Edmonton, AB, Canada) also equipped with a combined sealed glass electrode. Prior to measurements, cheeses were grated and tempered for $30 \mathrm{~min}$ at room temperature. The buffering capacity $(\Delta \mathrm{B} / \Delta \mathrm{pH})$ was determined (Hassan et al., 2004). The $\mathrm{pH}$ measurements were performed with a $0.5 \mathrm{~N} \mathrm{HCl}$ or $\mathrm{NaOH}$ solution (Anachemia Canada Inc., Montréal, QC, Canada) using a TitraLab TIM856 automatic titrator (Radiometer Analytical Sas, France) equipped with a combined sealed glass electrode. The titration data were recorded with the TitraMaster85 software (Radiometer Analytical SAS, Lyon, France) and processed with the TableCurve software (v.5.01., Systat Software Inc., San Jose, CA). The composition of milk, whey, cream, and UF retentate was determined in duplicate by using a Milko Scan infrared detector (FT-120 Foss North America, Eden Prairie, MN). The composition of Cheddar cheeses was determined in triplicate as described by St-Gelais et al. (2009). Milk or cheese samples $(11 \mathrm{~g})$ were diluted in $99 \mathrm{~mL}$ of $0.1 \%$ sterile peptone solution and homogenized using a Stomacher (model 400, Seward Medical, London, UK). To allow disintegration of long chains of lactococci, $3 \mathrm{~g}$ of 4-mm glass beads were used in all subsequent dilution bottles, which were vigorously shaken 40 times before plating on M17 agar medium (St-Gelais et al., 1992b). The evolution of proteolysis in cheeses was followed by determining the total nitrogen and water-soluble nitrogen according to Christensen et al. (1991). Results were expressed as the ratio of soluble nitrogen to total 
Table 1. Composition and buffering capacity of cheese milk

\begin{tabular}{lcccc}
\hline & \multicolumn{3}{c}{ Cheese milk } \\
\cline { 2 - 3 } Item & $1 \times$ & $1.4 \times$ & $1.8 \times$ & SEM \\
\hline Total proteins (\%) & $3.37^{\mathrm{c}}$ & $4.71^{\mathrm{b}}$ & $6.01^{\mathrm{a}}$ & 0.03 \\
Caseins (\%) & $2.54^{\mathrm{c}}$ & $3.53^{\mathrm{b}}$ & $4.50^{\mathrm{a}}$ & 0.02 \\
Noncaseins (\%) & $0.83^{\mathrm{c}}$ & $1.18^{\mathrm{b}}$ & $1.51^{\mathrm{a}}$ & 0.01 \\
Fat (\%) & $3.71^{\mathrm{c}}$ & $5.14^{\mathrm{b}}$ & $6.70^{\mathrm{a}}$ & 0.04 \\
DM (\%) & $12.41^{\mathrm{c}}$ & $15.15^{\mathrm{b}}$ & $18.00^{\mathrm{a}}$ & 0.04 \\
Lactose (\%) & $4.33^{\mathrm{a}}$ & $4.21^{\mathrm{b}}$ & $4.03^{\mathrm{c}}$ & 0.01 \\
Ashes (\%) & $0.71^{\mathrm{c}}$ & $0.80^{\mathrm{b}}$ & $0.90^{\mathrm{a}}$ & 0.01 \\
Vitamin D (IU/g of milk) & $462^{\mathrm{a}}$ & $453^{\mathrm{b}}$ & $442^{\mathrm{c}}$ & 2 \\
Buffering capacity $(\Delta \mathrm{B} / \Delta \mathrm{pH})$ & $0.0028^{\mathrm{c}}$ & $0.0081^{\mathrm{b}}$ & $0.0135^{\mathrm{a}}$ & 0.0008 \\
\hline
\end{tabular}

${ }^{a-c}$ Means within a row with the same superscripts do not differ $(P>0.05)$.

nitrogen. Cheese hardness was determined by using a TA-XT2 texture analyzer (Mono-Research Laboratories Ltd., Brompton, ON, Canada). Cheese cylinders (1 $\mathrm{cm}^{3}$ ) were bored and placed into a Petri dish for $1 \mathrm{~h}$ at $21^{\circ} \mathrm{C}$ before compression tests. For each cheese sample, 13 cylinders were individually compressed to a deformation of $50 \%$ using a $25-\mathrm{mm}$ cylinder attached to a $5-\mathrm{kg}$ cell. The deformation speed of the samples was 0.4 $\mathrm{mm} / \mathrm{s}$. An ANOVA was performed according to a factorial design to determine the effect of milk concentration $(1 \times, 1.4 \times, 1.8 \times)$ on milk composition and buffering capacity and also on cheese composition and cheese yields. A split-plot design was applied to determine the effect of milk concentration and cheese manufacturing steps on proportion of whey drained and also on vitamin D lost. Milk concentration and replicates were the main plots, and cheese manufacturing steps were the subplots. Finally, a split-plot design was applied to determine the effect of milk concentration and storage time on the evolution of vitamin $\mathrm{D}$ concentration, $\mathrm{pH}$, population of lactococci, cheese proteolysis, and hardness. Milk concentration and replicates were the mains plots and storage time was the subplot. The experiment was replicated 3 times, and significant differences were tested at $P \leq 0.05$ according to the SAS/STAT procedure (version 9.3, SAS Institute Inc., Cary, NC).

The use of UF retentate to enrich cheese milk with a total protein to fat ratio of 0.91 had significantly $(P \leq 0.05)$ modified the composition of cheese milks (Table 1). The levels of proteins, fat, ash, DM, and the buffering capacity increased significantly $(P \leq 0.05)$ with the concentration factor. An opposite trend was observed with the lactose content. Even though the vitamin concentration was slightly lower in $1.8 \times$ milk, the targeted vitamin $\mathrm{D}$ concentration (450 IU/g milk) could be considered reached (Table 1 ). In addition, the vitamin content of all milks was the same before and after pasteurization (results not shown). These results are in agreement with those of Krauss (1933), Wagner et al. (2008a), and Kaushik et al. (2014) who observed no effect of pasteurization $\left(63^{\circ} \mathrm{C}, 30 \mathrm{~min}\right.$ and $72^{\circ} \mathrm{C}, 16$ s) or sterilization $\left(116^{\circ} \mathrm{C}, 15 \mathrm{~min}\right)$ on the vitamin $\mathrm{D}$ concentration in milk.

As the inoculation rate and the addition of rennet were adjusted according to milk protein concentration, the $\mathrm{pH}$ decrease and time required for each manufacturing step were not statistically different $(P \leq 0.05$; results not shown). However, during cheese manufacturing, the lactic acid production was significantly different $(P \leq$ $0.05)$ and increased as the cheese milk protein concentration increased. The lactic acid concentration in control, $1.4 \times$, and $1.8 \times$ cheesemilks was, respectively, 1.37 , 1.68 , and $1.98 \mathrm{~g} / \mathrm{L}$ after pasteurization and 1.63, 1.94, and $2.20 \mathrm{~g} / \mathrm{L}$ before renneting. The cheese milk buffering capacity, which depends on the protein and mineral contents in milk (Srilaorkul et al., 1989; St-Gelais et al., 1992a), increased with the protein content (Table 1). Consequently, the starter produced larger amounts of lactic acid to decrease $\mathrm{pH}$ at the same level.

As expected, the amount of whey at the wheying-off step was significantly lower $(P \leq 0.05)$ for concentrated milks, but no difference was observed during cheddaring and pressing steps (Table 2). As a result, the loss of vitamin D was significantly reduced as the milk concentration increased (Table 2). Indeed, $25.5 \%$ of the vitamin $\mathrm{D}$ added into control cheese was lost in the whey compared with 21.5 and $19.8 \%$ lost in the whey of $1.4 \times$ and $1.8 \times$ cheeses, respectively. Furthermore, these could also be explained by the higher casein and whey protein content of the concentrated milks (Table 1). The hydrophobic sites of $\beta$-casein and $\beta$-lactoglobulin could bind vitamin D (Forrest et al., 2005; Diarrassouba et al., 2013), resulting in a better retention of vitamin $\mathrm{D}$ in cheeses made from concentrated milk. Because vitamin $\mathrm{D}$ retention varies greatly depending on the form of vitamin used (emulsion, oil, powder) as well as the type and fat content of the cheeses, results reported in the literature differ. Ganesan et al. (2011) reported 
Table 2. Proportion of whey drained and vitamin D lost during cheese manufacturing

\begin{tabular}{lrrrr}
\hline & \multicolumn{3}{c}{ Cheese } & \\
\cline { 2 - 3 } Item & $1 \times$ & $1.4 \times$ & $1.8 \times$ & SEM \\
\hline Whey (\% milk volume) & $83.86^{\mathrm{d}}$ & $79.43^{\mathrm{e}}$ & $75.53^{\mathrm{f}}$ & 0.28 \\
Wheying-off & $4.25^{\mathrm{g}}$ & $4.15^{\mathrm{g}}$ & $3.94^{\mathrm{g}}$ & \\
Cheddaring & $1.10^{\mathrm{h}}$ & $1.42^{\mathrm{h}}$ & $1.42^{\mathrm{h}}$ & \\
Pressing & $89.21^{\mathrm{a}}$ & $85.00^{\mathrm{b}}$ & $80.89^{\mathrm{c}}$ & \\
Total & & & & \\
Vitamin D (\%) & $24.89^{\mathrm{a}}$ & $20.99^{\mathrm{b}}$ & $19.19^{\mathrm{b}}$ & 0.90 \\
Wheying-off & $0.35^{\mathrm{c}}$ & $0.27^{\mathrm{c}}$ & $0.34^{\mathrm{c}}$ & \\
Cheddaring & $0.21^{\mathrm{c}}$ & $0.23^{\mathrm{c}}$ & $0.26^{\mathrm{c}}$ & \\
Pressing & $25.45^{\mathrm{a}}$ & $21.49^{\mathrm{b}}$ & $19.79^{\mathrm{b}}$ & \\
Total & & & & \\
\hline
\end{tabular}

$\overline{\mathrm{a}-\mathrm{h}}$ Means within a group (whey or vitamin $\mathrm{D}$ ) with the same superscripts do not differ $(P>0.05)$.

more than $80 \%$ vitamin $\mathrm{D}_{3}$ retention in Cheddar cheese curd. Tippetts et al. (2012) observed retentions of only 64 and $71 \%$ when commercial nonemulsified vitamin $\mathrm{D}_{3}$ oil was added in skim milk and whole milk, respectively. Ninety percent of vitamin D was retained in fortified regular Cheddar cheese but only $55 \%$ in fortified lowfat cheese (Wagner et al., 2008a). Banville et al. (2000) reported significantly higher retention rates when vitamin D was entrapped in liposomes $(61 \%)$ compared with vitamin D homogenized in cream $(40 \%)$ or added to milk $(43 \%)$.

During cheese ripening, the concentration of vitamin D remained high in each cheese (Figure 1) and no significant change was observed. These results are in agreement with several authors who observed the stability of vitamin D in cheese during 3 mo (Kazmi et al., 2007), 5 mo (Banville et al., 2000), 9 mo (Upreti et al., 2002), and 12 mo (Wagner et al., 2008a). Likewise, Ganesan et al. (2011) reported no loss of vitamin D in Cheddar type cheese made from different forms of vitamin $\mathrm{D}$ during a 9 -mo ripening period. These results indicate that the cheese matrix as well as the metabolic activities of bacteria and enzymes involved during cheese ripening did not affect vitamin D.

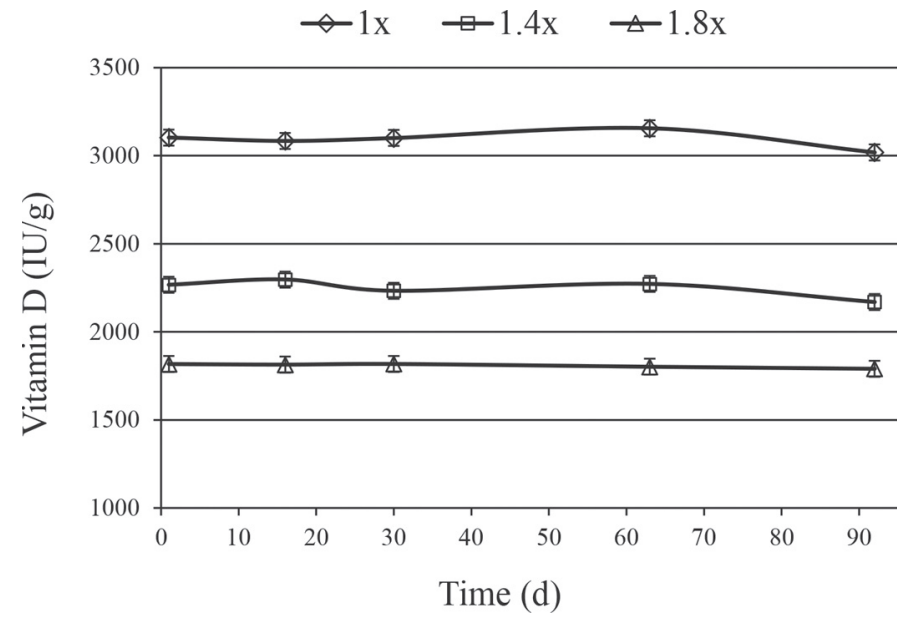

Figure 1. Vitamin D content (IU/g) in cheeses during ripening. Error bars represent the SEM.

The composition of all cheeses was statistically similar $(P>0.05)$ except for the ashes and moisture contents. The concentration of ashes increased, whereas that of moisture decreased as the milk concentration increased (Table 3). Similar results were obtained by Guinee et al. (1996, 2006). It is known that cheeses produced from UF milk or milk enriched with UF retentate contain higher amounts of minerals (St-Gelais et al., 1998, 2001). As the time process was similar for each cheese production, the lower moisture content of the cheeses made from concentrated milk could be related to the higher casein/soluble salts ratio, which would promote the syneresis (Green et al., 1981).

As observed by St-Gelais et al. (1997), cheese pH values during ripening were significantly $(P \leq 0.05)$ higher in $1.4 \times$ and $1.8 \times$ cheeses than in control cheese (Figure 2A). These higher $\mathrm{pH}$ values were due to the higher buffering capacity in cheeses made with concentrated milks (Table 3 ). The buffering capacity provided a protective environment for bacteria (St-Gelais et al., 1992b) and was also responsible for the higher lactococ-

Table 3. Cheese composition, buffering capacity, and yield

\begin{tabular}{lcccc}
\hline & \multicolumn{3}{c}{ Cheese } & \\
\cline { 2 - 3 } Item & $1 \times$ & $1.4 \times$ & $1.8 \times$ & SEM \\
\hline Total proteins (\%) & $25.31^{\mathrm{a}}$ & $25.50^{\mathrm{a}}$ & $25.68^{\mathrm{a}}$ & 0.19 \\
Fat $(\%)$ & $31.39^{\mathrm{a}}$ & $31.73^{\mathrm{a}}$ & $31.56^{\mathrm{a}}$ & 0.42 \\
Moisture (\%) & $37.92^{\mathrm{a}}$ & $36.28^{\mathrm{a}}$ & $35.50^{\mathrm{b}}$ & 0.51 \\
Salt/moisture (\%) & $3.83^{\mathrm{a}}$ & $3.90^{\mathrm{a}}$ & $4.10^{\mathrm{a}}$ & 0.08 \\
Ashes (\%) & $3.39^{\mathrm{c}}$ & $3.62^{\mathrm{b}}$ & $3.85^{\mathrm{a}}$ & 0.03 \\
Vitamin D (IU/g of cheese) & $3,084^{\mathrm{a}}$ & $2,282^{\mathrm{b}}$ & $1,814^{\mathrm{c}}$ & 46 \\
Buffering capacity $(\Delta \mathrm{B} / \Delta \mathrm{pH})$ & $0.0074^{\mathrm{a}}$ & $0.0084^{\mathrm{a}}$ & $0.0097^{\mathrm{a}}$ & 0.0006 \\
Cheese yield $(\%)$ & $10.3^{\mathrm{c}}$ & $14.4^{\mathrm{b}}$ & $18.4^{\mathrm{a}}$ & 0.2 \\
\hline a-c & & &
\end{tabular}

${ }^{\mathrm{a}-\mathrm{c}}$ Means within a row with the same superscripts do not differ $(P>0.05)$. 

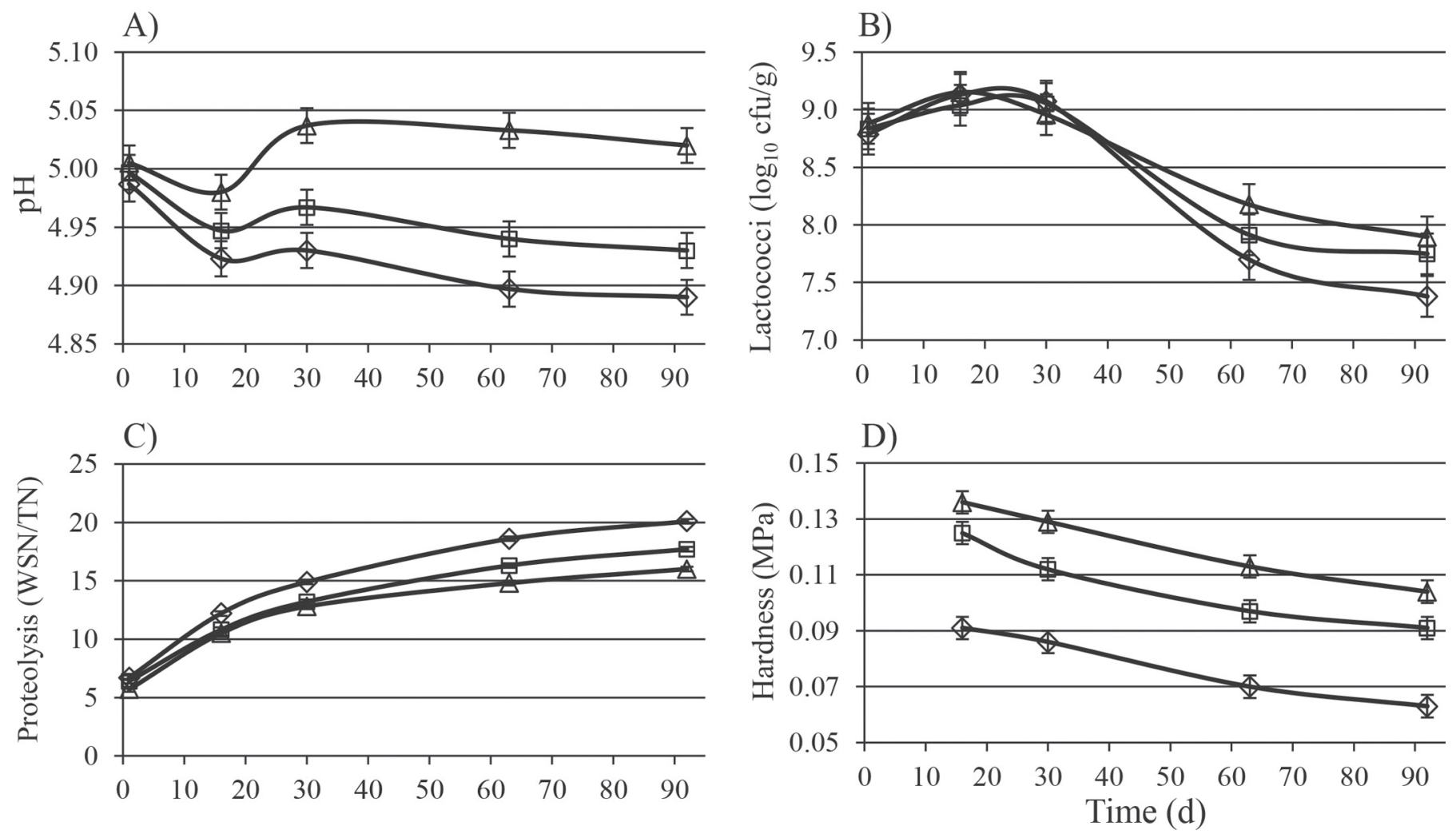

Figure 2. $\mathrm{pH}$ values $(\mathrm{A})$, lactococci concentrations $(\mathrm{B})$, proteolysis (water-soluble $\mathrm{N} /$ total N; C), and hardness $(\mathrm{D})$ in control cheese $(1 \times$ ) and in $1.4 \times$ and $1.8 \times$ cheeses during ripening. Error bars represent the SEM.

ci populations during ripening of $1.4 \times$ and $1.8 \times$ cheeses (Figure $2 \mathrm{~B}$ ) as previously reported by St-Gelais et al. (1997), Midje et al. (2000), and Desfossés-Foucault et al. (2013).

The significant $(P \leq 0.05)$ slower proteolysis and the higher hardness observed for $1.4 \times$ and $1.8 \times$ cheeses (Figure 2C and 2D, respectively) were also observed by Guinee et al. (1994, 1996). Compared with control cheese, the higher hardness of concentrated cheeses could be due to their lower moisture and higher mineral contents (Table 3).

Our findings confirm that vitamin $\mathrm{D}$ losses in whey could be reduced by the concentration of milk by ultrafiltration before cheese manufacture. As reported in previous studies (Banville et al., 2000; Kazmi et al., 2007; Wagner et al., 2008a; Kaushik et al., 2014), vitamin D remains stable during Cheddar cheese processing and ripening. Moreover, the effect of milk concentration on the buffering capacity and the acidifying activity of the starters as well their survival during cheese ripening has been confirmed. Based on the results obtained, the application of UF to cheesemilk results in small but significant decreases in vitamin D loss in whey. How- ever, in other types of cheeses with reduced draining such as soft cheeses, it could be possible to concentrate the milk before renneting until the same solid levels as in the conventional cheese. Consequently, the draining step is eliminated and the totality of vitamin could be retained in the cheese. This type of cheese turns out to be a useful vector for the introduction of an alternative vitamin D source for consumers or, with reduced fat, as a new nutritional type product.

\section{ACKNOWLEDGMENTS}

The authors thank the Dairy Farmers of Canada (Montreal) for the financial support, and Gaétan Bélanger, Annie Caron, Sophie Turcot, Julien Baret, and Floriane De Biasio (Food Research Center, Agriculture and Agri-Food Canada, St-Hyacinthe, Canada) for their expert advice and technical support.

\section{REFERENCES}

Banville, C., J. C. Vuillemard, and C. Lacroix. 2000. Comparison of different methods for fortifying Cheddar cheese with vitamin D. Int. Dairy J. 10:375-382. 
Calvo, M., and S. Whiting. 2013. Vitamin D fortification in North America: Current status and future considerations. Pages 259-275 in Handbook of Food Fortification and Health. V. R. Preedy, R. Srirajaskanthan, and V. B. Patel, ed. Springer, New York, NY.

Christensen, T. M. I. E., K. R. Kristiansen, and H. Werner. 1991. Casein hydrolysis in cheeses manufactured traditionally and by ultrafiltration technique. Milchwissenschaft 46:279-283.

Combs, G. F., Jr. 2012. Vitamin D. Pages 139-180 in The Vitamins. 4th ed. Academic Press, San Diego, CA.

Desfossés-Foucault, É., G. LaPointe, and D. Roy. 2013. Dynamics and rRNA transcriptional activity of lactococci and lactobacilli during Cheddar cheese ripening. Int. J. Food Microbiol. 166:117-124.

Diarrassouba, F., G. Remondetto, L. Liang, G. Garrait, E. Beyssac, and M. Subirade. 2013. Effects of gastrointestinal $\mathrm{pH}$ conditions on the stability of the $\beta$-lactoglobulin/vitamin $\mathrm{D}_{3}$ complex and on the solubility of vitamin $\mathrm{D}_{3}$. Food Res. Int. 52:515-521.

Forrest, S. A., R. Y. Yada, and D. Rousseau. 2005. Interactions of vitamin $\mathrm{D}_{3}$ with bovine $\beta$-lactoglobulin $\mathrm{A}$ and $\beta$-casein. J. Agric. Food Chem. 53:8003-8009.

Ganesan, B., C. Brothersen, and D. J. McMahon. 2011. Fortification of Cheddar cheese with vitamin D does not alter cheese flavor perception. J. Dairy Sci. 94:3708-3714.

Green, M. L., F. A. Glover, E. M. W. Scurlock, R. J. Marshall, and D. S. Hatfield. 1981. Effect of use of milk concentrated by ultrafiltration on the manufacture and ripening of Cheddar cheese. J. Dairy Res. 48:333-341

Guinee, T. P., D. J. O'Callaghan, E. O. Mulholland, and D. Harrington. 1996. Milk protein standardization by ultrafiltration for Cheddar cheese manufacture. J. Dairy Res. 63:281-293.

Guinee, T. P., B. T. O'Kennedy, and P. M. Kelly. 2006. Effect of milk protein standardization using different methods on the composition and yields of Cheddar cheese. J. Dairy Sci. 89:468-482.

Guinee, T. P., P. D. Pudja, and E. O. Mulholland. 1994. Effect of milk protein standardization, by ultrafiltration, on the manufacture, composition and maturation of Cheddar cheese. J. Dairy Res. 61:117-131.

Hassan, A., M. E. Johnson, and J. A. Lucey. 2004. Changes in the proportions of soluble and insoluble calcium during the ripening of Cheddar cheese. J. Dairy Sci. 87:854-862.

Holick, M. F. 2011. Photobiology of vitamin D. Pages 13-22 in Vitamin D. 3rd ed. F. David, J. W. Pike, and S. A. John, ed. Academic Press, San Diego, CA.

Institute of Medicine. 2011. Dietary reference intakes for calcium and vitamin D. A. C. Ross, C. L. Taylor, A. L. Yaktine, and H. B. D. Valle, ed. The National Academies Press, Washington, DC.

Holick, M. F., and T. C. Chen. 2008. Vitamin D deficiency: A worldwide problem with health consequences. Am. J. Clin. Nutr. 87:1080S-1086S

Kaushik, R., B. Sachdeva, and S. Arora. 2014. Vitamin $D_{2}$ stability in milk during processing, packaging and storage. LWT Food Sci. Technol. (Campinas.) 56:421-426.

Kazmi, S. A., R. Vieth, and D. Rousseau. 2007. Vitamin $\mathrm{D}_{3}$ fortification and quantification in processed dairy products. Int. Dairy J. $17: 753-759$.
Krauss, W. E. 1933. Studies on the nutritive value of milk. II. The effect of pasteurization on some of the nutritive properties of milk. Ohio Agric. Exp. Stn. Bull. 518:1-33.

Lips, P. 2010. Worldwide status of vitamin D nutrition. J. Steroid Biochem. Mol. Biol. 121:297-300.

Midje, D. L., E. D. Bastian, H. A. Morris, F. B. Martin, T. Bridgeman, and Z. Vickers. 2000. Flavor enhancement of reduced fat Cheddar cheese using an integrated culturing system. J. Agric. Food Chem. 48:1630-1636.

Sacco, J. 2013. Food fortification policy in Canada. Pages 59-71 in Handbook of Food Fortification and Health. V. R. Preedy, R. Srirajaskanthan, and V. B. Patel, ed. Springer, New York, NY.

Srilaorkul, S., L. Ozimek, F. Wolfe, and J. Dziuba. 1989. The effect of ultrafiltration on physicochemical properties of retentate. Can. Inst. Food Sci. Technol. J. 22:6-62.

St-Gelais, D., J. Fortin, and S. Hache. 2001. Effect of different ultrafiltered milk retentate powders on the production of Cheddar cheese. Milchwissenschaft-Milk Sci. Int. 56:437-440.

St-Gelais, D., S. Haché, and M. Groslouis. 1992a. Combined effects of temperature, acidification and diafiltration on composition of skim milk retentate and permeate. J. Dairy Sci. 75:1167-1172.

St-Gelais, D., J. Lessard, C. P. Champagne, and J. C. Vuillemard. 2009. Production of fresh Cheddar cheese curds with controlled postacidification and enhanced flavor. J. Dairy Sci. 92:1856-1863.

St-Gelais, D., C. A. Passey, S. Hache, and D. Roy. 1997. Production of low-fat cheddar cheese from low and high mineral retentate powders and different fractions of milkfat globules. Int. Dairy J. 7:733-741.

St-Gelais, D., D. Roy, and S. Haché. 1992b. Growth and activities of Lactococcus lactis in milk enriched with low mineral retentate powders. J. Dairy Sci. 75:2344-2352.

St-Gelais, D., D. Roy, and P. Audet. 1998. Manufacture and composition of low fat Cheddar cheese from milk enriched with different protein concentrate powders. Food Res. Int. 31:137-145.

Tippetts, M., S. Martini, C. Brothersen, and D. J. MacMahon. 2012. Fortification of cheese with vitamin D3 using dairy protein emulsions as delivery systems. J. Dairy Sci. 95:4768-4774.

Upreti, P., V. V. Mistry, and J. J. Warthesen. 2002. Estimation and fortification of vitamin $\mathrm{D}_{3}$ in pasteurized process cheese. J. Dairy Sci. 85:3173-3181.

Wagner, D., D. Rousseau, G. Sidhom, M. Pouliot, P. Audet, and R. Vieth. 2008a. Vitamin $\mathrm{D}_{3}$ fortification, quantification, and longterm stability in cheddar and low-fat cheeses. J. Agric. Food Chem. 56:7964-7969.

Wagner, D., G. Sidhom, S. J. Whiting, D. Rousseau, and R. Vieth 2008b. The bioavailability of vitamin D from fortified cheeses and supplements is equivalent in adults. J. Nutr. 138:1365-1371.

Whiting, S. J., K. A. Langlois, H. Vatanparast, and L. S. GreeneFinestone. 2011. The vitamin D status of Canadians relative to the 2011 Dietary Reference Intakes: An examination in children and adults with and without supplement use. Am. J. Clin. Nutr. 94:128-135. 